\title{
Rust Disease of Pea: A Review
}

\author{
Vinod Upadhyay ${ }^{1 *}$, Kuldip Medhi ${ }^{1}$, Puja Pandey ${ }^{2}$, Palash Thengal ${ }^{1}$, \\ Sunil Kumar Paul ${ }^{1}$ and K.P.S. Kushwaha ${ }^{3}$ \\ ${ }^{1}$ Regional Agricultural Research Station, Assam Agricultural University, \\ Gossaigaon-783360, Assam, India \\ ${ }^{2}$ Department of Plant Pathology, Anand Agricultural University, Anand, Gujarat India \\ ${ }^{3}$ Department of Plant Pathology, G.B. Pant University of Agriculture and Technology, \\ Pantnagar, Uttarakhand, India
}

*Corresponding author

\begin{tabular}{|c|c|}
\hline & A B S T R A C T \\
\hline Keywords & \multirow{4}{*}{$\begin{array}{l}\text { Pulses being important source of protein are essential adjunct to predominantly cereal } \\
\text { based diet of large Indian population. Among all major pulses grown in India, pea (Pisum } \\
\text { sativum L.) is considered as one of the important pulse crop. Pea diseases are major } \\
\text { constraints to pea production in the developing countries. These diseases affects the crop } \\
\text { both quantitatively (yield) as well as qualitatively (seed quality). Among these, the rust of } \\
\text { pea caused by Uromyces viciae-fabae (Pers.) J. Schrot is considered as most important } \\
\text { under warm and humid conditions. This review explains the geographical distribution, } \\
\text { biology, epidemiology of pea rust pathogen and finally the different management aspects } \\
\text { of rust disease of pea, such as the alteration in date of sowing, use of resistant cultivars, } \\
\text { role of biotic and abiotic elicitors in induction of host plant resistance and lastly chemical } \\
\text { control measures which cannot be avoided and must be taken into consideration up to } \\
\text { environmentally safe level. }\end{array}$} \\
\hline $\begin{array}{l}\text { Rust Disease } \\
\text { Pea, } \\
\text { Pisum sativum }\end{array}$ & \\
\hline Article Info & \\
\hline $\begin{array}{l}\text { Accepted: } \\
\text { 04 March } 2019 \\
\text { Available Online: } \\
10 \text { April } 2019\end{array}$ & \\
\hline
\end{tabular}

\section{Introduction}

A large proportion of Indian population is vegetarian and pulses are the main source of protein for them. The protein content in pulses is about $18-25$ per cent which makes pulse one of the cheapest source of protein for human consumption. Pulses are the member of the family leguminoceae, capable of utilizing Rhizobium bacterium in their root nodules, thus fixing atmospheric nitrogen and helps in improving soil fertility. Pulses leave behind reasonable quantity of nitrogen in the soil and add up to $30 \mathrm{~kg} \mathrm{~N} / \mathrm{ha}$ to it. Pulses are also suitable for various crop rotations under rainfed conditions and they play vital role in sustainable agriculture in our country. In crop rotation, it helps in improvement of soil fertility and yield of succeeding crops (Rana and Sharma, 1993).

India is the largest producer, consumer and importer of pulses in the world. Pulses are grown about 24-26 million hectares of area producing 17-19 million tonnes of pulses annually in India which accounts for over one 
third of the total world area and over 20 per cent of total world pulse production. Per capita production and availability of pulses in the country has observed quick decline. Per capita net pulse availability has declined from around 60 grams per day in the 1950 s to 40 grams in the 1980s and further to around 35 grams per day in 2000s. However, in the last four years, there has been significant increase in consumption averaging around 50 grams due to higher production, because of National Food Security Mission (NFSM), with major emphasis on pulses and their imports, mostly of dry peas from Canada and Australia (IIPR, 2014).

Major pulses grown in India include chickpea or bengal gram (Cicer arietinum), pigeonpea or red gram (Cajanus cajan), lentil (Lens culinaris), urdbean or black gram (Vigna mungo), mungbean or green gram (Vigna radiata), lablab bean (Lablab purpureus), moth bean (Vigna aconitifolia), horse gram (Dolichos uniflorus), pea (Pisum sativum L.), grass pea or khesari (Lathyrus sativus), cowpea (Vigna unguiculata), and broad bean or faba bean (Vicia faba).

Pea (Pisum sativum L.), the famous plant in which G.J. Mendel worked out Mendel Laws and Genetic Principles, is a noble and aristocratic vegetable. The crop is cultivated for its tender and immature pods for use as vegetable and mature dry pods for use as a pulse. In both cases, seeds are separated and used as vegetable or pulse. Tender seeds are also used in soups. Canned, frozen and dehydrated peas are very common for use during off-season. Like any other legume crop, pea is an integral component of sustainable agriculture due to its soil enriching and conditioning properties (Singh, 1984). Based on genetic diversity Vavilov (1926) listed different centre of origin for pea comprising Central Asia, the Near East, Abyssinia and the Mediterranean. Cultivated garden pea is not seen in wild state and it might have been originated from wild field pea or other related species.

During 2012-13, Pea (Pisum sativum L.) occupies an area of 0.76 million hectares with a production 0.84 million tonnes and productivity of $1100 \mathrm{~kg} / \mathrm{ha}$ in our country (NCAER, 2014). Pea is a high quality protein rich pulse and vegetable crop. Dry pea generally contains 23 per cent protein, 48 per cent starch, eight per cent sugar, four per cent lipid, seven per cent crude fibre and three per cent ash (Duke and Ayensu, 1985).

Pea is affected by a number of fungal (rust, powdery mildew, downy mildew, root rot, alternaria blight, aschochyta blight, wilt, anthracnose, cercospora leaf spot, damping off, seedling rot etc.), bacterial (bacterial blight and brown spot), nematode (cyst nematode, lesion nematode and root-knot nematode) and viral diseases (cucumber mosaic virus, pea early browning virus, pea enation mosaic, pea mosaic, pea seed borne mosaic, pea streak and pea stunt). These diseases, under the right conditions, can significantly decrease both yield and quality. Among these, the rust of pea caused by Uromyces viciae-fabae (Pers.) J. Schrot (syn. Uromyces fabae (Pers.) de Bary) is considered the most important under warm and humid conditions (Chand et al., 2004).

\section{Symptomatology}

The first symptoms appear with the development of aecia. The yellow aecia appear first on the undersurface of the leaves, stems and petioles. The formation of aecial stage is preceded by a slight yellowing which gradually turns brown. The uredopustules are powdery light brown in appearance. All the four stages develop on every green part of the host including the pods. The teleutopustules occur in the same sources as the uredia and 
develop from the same mycelium (Singh, 1973). Thatcher (1939) studied the effect of $U$. fabae on pea. He pointed out that fungus increased the permeability of the host cell by secreting some metabolites, which ultimately prove fatal. Hahn et. al. (1977) also reported that a putative amino acid transporter was specifically expressed in haustoria of the rust fungus Uromyces-fabae, which may be the cause of increased permeability of the host cell. Staples (1968) and Haung and Staples (1982) proposed the synthesis of proteins during differentiation of the bean rust fungus. Staples and Stahmann (1964) have also reported the change in protein and several enzymes in susceptibile bean leaves after rust infection.

\section{Biology of Uromyces fabae}

\section{Pathogen description}

Two species of Uromyces have been reported to cause rust of pea. One of them $U$. pisi (Persoon) de Bary, has been reported from several European countries (Deutelmoser, 1926; Mayer, 1947; Palter and Stetbiner, 1957). It is a heteroecious species having its aecial stage in Euphorbia cyparissias and rarely occurs in India. In India, another species U. fabae (Pers.) de Bary has been found to cause pea rust (Butler, 1918; Prasada et al., 1948; Kapooria et al., 1966).

Uromyces fabae (Uromyces viciae-fabae) the rust of pea was first reported by Persoon in 1801. Later de Bary (1862) changed the genus and renamed it as Uromyces fabae (Pers.) de Bary. The pathogen $U$. fabae is described as autoecious rust with aeciospores, urediospores and teliospores found on the same host plant (Arthur and Cummins, 1962; Gaumann, 1998). Gaumann proposed that the fungus be classified into nine formae speciales each with host range limited to two or three species. The isolates of Uromyces viciae- fabae share so many hosts in common that it is impossible to classify them into formae speciales (Conner and Bernier, 1982). Based on the distinctive shape and dimension of substomatal vesicle, $U$. viciae-fabae has been described as a species complex (Emeran et $a l$. , 2005). The peridium of aecium in $U$. fabae is short, whitish and cup shaped. The aeciospores are round to angular or elliptical, yellow in colour with fine warts. They measure 14-22 microns in diameter. The uredospores are round to ovate light brown echinulate with 3-4 germpores and measure $20-30 \times 18-26$ microns. The teliospores are subglobose to 20 ovate, thick walled, with flattened apex, smooth, single celled, pedecellate and measure 25-38 $\times$ 18-27 microns in size (Singh, 1973). Prasada and Verma (1948) working with Uromyces fabae from lentil found that infection with aeciospores at lower temperatures $\left(17-26^{\circ} \mathrm{C}\right)$ results in the formation of secondary aecia, while at $25^{\circ} \mathrm{C}$ the infection causes development of uredia. No infection by aeciospores occurs at $30^{\circ} \mathrm{C}$. Optimum temperature for germination of uredospores is $16-22^{\circ} \mathrm{C}$, while uredospores germination does not occur at $28-29^{\circ} \mathrm{C}$. The teleutospores of lentil rust can germinate at $12-22^{\circ} \mathrm{C}$. The fungus completes its life cycle on peas and is further endowed with survival potential in the telial stage (Singh, 1973).

\section{Taxonomy and Nomenclature}

Uromyces fabae is an autoecious and heterothallic fungus forming all the four type of spores viz., pycniospores/spermatiospores, aeciospores, urediospores and teliospores on pea only. Pycnia are small, flask shaped and produced as yellowish flecks on upper surface of leaves with a common nector drop at mouth. As the haploid pustules remained unfertilized the formation of pycnia, with separate scanty nectar drops on the lower surface of the leaves was observed (Prasada 
and Singh, 1975). Rust of pea is caused by fungus Uromyces viciae-fabae (Pers.) J. Schrot. belongs to the phylum Basidiomycota, class Urediniomycetes, order Uredinales (rust fungi) and family Pucciniaceae (Alexopoulos et al., 1996). According to recent classification by Kirk et al., $(2001,2008)$ the systemic position of the $U$. viciae-fabae belongs to kingdom Fungi, phylum Basidiomycota, class Pucciniomycetes, order Pucciniales and family Pucciniaceae.

\section{Host range}

Prasada and Verma (1948) found that several species of Vicia, Lathyrus, Pisum and Lentil are susceptible to $U$. fabae in India and abroad. In India, species of Vicia, Lathyrus, and Pisum are described as host plant for $U$. viciae fabae (Pers.) J. Schrot (Kapooria and Sinha, 1966). Bilgrami et al., (1979) reported the occurrence of this pathogen on various host species of pea, lentil and lathyrus. Vicia faba L., V. biennes L., V. hirsuta L., and $V$. arborensis L. were described as highly susceptible to Uromyces fabae and Vicia sativa and Lathyrus aphaca were found to be disease free. Conner and Bernier (1982) reported a total of 52 species of Vicia faba and 22 species of Lathyrus to be infected by U. viciae-fabae (Pers.) J. Schrot. Uppal (1993) has also reported that U. fabae infect several species of Vicia, Lathyrus, Pisum and Lentil in India and abroad.

\section{Geographical distribution}

Pea rust ( $U$. fabae) is of worldwide occurrence and attacks number of host species belonging to different genera of the family Leguminosae in the Indo-Gangetic plains (Butler, 1918). There were reports of occurrence of $U$. fabae from most of the places of India including eastern India (Gupta, 1990; Chand et al., 1997), central India (Narsinghani et al., 1980), southern parts of
India (Sokhi et al., 1974; Kumar et al., 1994) and from Himalayan region of Uttarakhand and Himachal Pradesh (Chauhan et al., 1991; Sharma, 1998). Survey of pea growing region of three districts of Bihar (Lal et al., 2007) and six district of Himachal Pradesh (Chauhan, 1988) state of India revealed that $U$. fabae was very serious in pea. Prasada and Verma, (1948) also reported the occurrence of $U$. fabae on lentil crop from Delhi. Roy (1949) in his list of fungi of Bengal recorded the prevalence of $U$. fabae on the leaves and stems of pea (Pisum sativum). Mitter and Tondon (1930); Pavgi and Upadhyay (1966) and Kapooria and Sinha (1966) reported the distribution of this pathogen in the regions of Uttar Pradesh, respectively. Baruah (1980) reported that rust infection on the pea plants is caused by both $U$. fabae and $U$. pisi of which $U$. pisi is of rare occurrence in India. Occurrence of $U$. fabae have been reported from Canada, Europe, Ethiopia, Australia and Iran in mild to severe forms on pea, lentil, alfalfa, broad bean and faba bean are also available (Conner and Bernier, 1982; Xue and Warkentin, 2002 and Sadravi et al., 2007). In the last few years, disease has been observed in almost epiphytotic form and could cause up to $20-100 \%$ losses in yield (Upadhyay et al.2015; Sharma, 1998).

\section{Life cycle}

Uromyces fabae is a macrocyclic rust fungus, it exhibits all five spore forms known for the Uredinales. It is autoecious, as all spores are produced by single host (Mendgen, 1997). After overwintering on residual plant material, diploid teliospores germinate in the spring with a metabasidium. After meiosis, the latter produces four haploid basidiospores with two different mating types. These spores after landing on a leaf of a host germinate and produce infection structures. Pycnia are produced which contain pycniospores. Pycniospore are exchanged between pycnia of 
different mating types and after spermatization, dikaryotization occurs in aecial primordial. An aecium differentiates and dikaryotic aeciospores are produced. These aeciospores germinate and form infection structures from which uredia develops, which produce urediospores. Urediospore is the major asexual spore form of rust fungi produced in massive amount through repeated infection of host plants during the summer. Urediospores are dispersed aerially and can travel thousands of kilometers (Brown and Hovmoller, 2002).

\section{Environmental factors affecting disease development}

Decision to apply one or more fungicide spray will depend on the risk of rust epidemic in a particular year. Rust epidemic is determined by interaction of three important factors namely, susceptible host, virulent pathogen and most important i.e. favourable environment for a particular period of time. Therefore, it is necessary to know the correlation between different meteorological parameters and rust severity. Rust disease of pea caused by Uromyces fabae is very severe under warm and humid conditions in Tarai region. Prasada and Verma (1948) reported that relatively low temperatures, $17-22^{\circ} \mathrm{C}$ result in formation of secondary aecia while at $25^{\circ} \mathrm{C}$ development of uredia takes place. Infection and pustules formation was high at $20^{\circ} \mathrm{C}$ under greenhouse and laboratory conditions. It was observed that relationship between severity of pea rust and duration of leaf wetness at above $20^{\circ} \mathrm{C}$ temperature may be useful in predicting disease outbreak if initial inoculum is present (Chauhan and Singh 1995). Atmospheric temperature around $20^{\circ} \mathrm{C}$ maximum and $5^{\circ} \mathrm{C}$ minimum with high $\mathrm{RH}$ (60-70\% mean weekly) and light shower or drizzle favour Uromyces viciae-fabae development and spread whereas temperature above $25^{\circ} \mathrm{C}$ and below $7-8^{\circ} \mathrm{C}$ along with rains disfavour rust spread (Mittal, 1997). Number of rainy days and rainfall during the crop season, play an important role in the spread of pea rust disease than any other weather parameters (Singh and Tripathi, 2004). Khare and Agrawal (1978) reported that high humidity, cloudy or drizzling weather with temperature of $20-22^{0} \mathrm{C}$ favours disease and those plants are more susceptible at flowering in lentil for Uromyces viciaefabae. Hazarika et al., (2000) demonstrated the effect of eight sowing dates on leaf spots and rust of groundnut in relation to weather factors during the crop season. They observed that, there was significant and positive correlation between the incidence of disease (leaf spot and rust disease) and weather factors i.e., rainfall, relative humidity and temperature. Negussie et al., (2005) observed that at $20^{\circ} \mathrm{C}$, dew period of at least three hours was required for minimum infection of lentil rust, whereas maximum infection occurred with a dew period of $24 \mathrm{hrs}$. Infection efficiency increased linearly as the duration of dew period increased from 0 to $24 \mathrm{hrs}$. The optimum germination of aeciospores, urediospores and teliospores was recorded at $20^{\circ} \mathrm{C}$. Viability of aeciospores and urediospores of $U$. viciae fabae (Pers.) de Bary decreased with increase in time, whereas, germination of teliospore after eight months of storage gave positive results (Joshi and Tripathi, 2012). They also found that age of plant had no direct relationship with rust appearance in lentil, while, $24 \mathrm{~h}$ leaf wetness after inoculation was found to be optimum for rust development. Singh et al., (2012) found significant and positive correlation between rust severity and temperature. However, disease severity has a strong negative correlation with grain yield $(\mathrm{kg} / \mathrm{ha})$, rainfall and relative humidity. Similar observations were recorded by Bal and Kumar (2012). Upadhyay et al., (2017) stated that rust disease was observed at a maximum temperature of 16.85 to $24.79^{\circ} \mathrm{C}, 8.09$ to 
$12.27^{\circ} \mathrm{C}$ minimum temperature, 90.30 to 95.70 percent morning Relative Humidity (RH), 54.80 to 78.40 percent afternoons $\mathrm{RH}$, 0.10 to $5.45 \mathrm{~mm}$ rainfall and wind velocity of 3.93 to $4.23 \mathrm{~km} / \mathrm{hr}$. Decision to spray fungicides will depend on the risk of rust epidemic. To help farmers in determining rust epidemic risk, there is need to work on developing forecast model for pea rust.

\section{Disease management strategies}

Cultural practices viz., planting time, planting geometry, intercropping and row spacing

Using principle of avoidance through alteration in date of sowing can be an effective way to disturb the interaction of three important factors namely host, pathogen and environment important for disease development and thus can be utilized as an effective cultural practice for the management of rust disease in field pea but the yield parameters should be taken into consideration. From past, many researchers have worked on these aspects which are mentioned here under:

Delayed in sowing i.e. after 15th October, increased the incidence of Uromyces viciaefabae and decreased grain yield (Sangar and Singh, 1994). Similarly, Singh et al., (1996) reported that incidence of rust (Uromyces viciae-fabae) increased as sowing was delayed. In contrary to this, Bhardwaj and Sharma (1996) reported that plants from 15 October sowing were taller, produced the highest number of marketable pods and highest green pod yield (4.74 t/ha) with lowest percent disease index of rust (Uromyces viciae-fabae). Similar observation was observed by Rai \& Gupta (2003) that rust intensity was found very high in late planted and closer spaced pea crop. In contrary to this, Singh Mittal (1997) observed that incidence of disease declined from the early to late sowing. Whereas, Tripathi and Rathi (2003) also studied on effects of different dates of sowing, inter-row spacing and intercropping on disease severity and grain yield of field pea. They reported that delayed sowing not only increased disease severity but also lower grain yield in plants having narrow spacing as compared to wider row spacing. They further emphasized that minimum disease severity was recorded in pea + mustard inter cropped plants followed by the pea + wheat, pea + linseed and pea + rajma. In oppose to Tripathi and Rathi (2003), Singh et al., (2012) found least rust severity when pea was planted on October $15^{\text {th }}$ during all the three crop seasons. The crop when sown lately i.e. sown on November 14, 29 and December $13^{\text {th }}$ recorded highest severity of rust. Similarly, Singh et al., (2014) studied the effects of cultural practices viz., planting time, planting geometry, intercropping and row direction on disease severity of field pea rust caused by Uromyces viciae fabae and grain yield. They found that late planting of pea has recorded the highest disease severity and minimum grain yield. They have also noticed that planting geometry i.e. row spacing has significant influence on disease severity $i e$. wider row spacing showed less rust severity than close spacing. Similarly to other researchers, he found that minimum rust severity was recorded when field pea was intercropped with mustard. However, planting direction has not significantly influenced rust severity. Upadhyay et al., (2018) studied the effect of alteration in date of sowing on rust severity and grain yield in field pea. Their investigation indicate that, early sown crop in 31st October, 7th November and 14th November face lower disease severity (8.6717.50 percent) with low area under disease progress value (81-198.67) and produce good yield (690.90-775.39 kg/ha) and test weight (162.34-175.34 g) whereas crop sown in 21st November, 28th November, 5th December 
and 12th December succumb to high disease severity (40-54.17 percent) showing high area under disease progress value (383.50-549.17) with low yield (429.06-581.95 kg/ha) and test weight (146.67-153.73 g).

\section{Screening of germplasms for disease resistance}

The use of host plant resistance is the best means of rust control (Bayaa and Erskine, 1998). Screening of field pea germplasms under field conditions for resistance to rust has been reported in India (Singh et al., 1995). Screening for rust severity indicated wide range of variations for rust resistance in the germplasm lines of pea and none of the genotypes tested were found to be free from infection (Narshinghani et al., 1980; Singh and Srivastava, 1985; Gupta, 1990; Kumar et al., 1994; Xue and Warkentin, 2002; Chand et al., 2004, Upadhyay et al., 2017). Rust severity is greatly influenced by the environment during infection initiation and disease development. This is the major bottleneck in screening and selection for rust resistance. Use of molecular markers would allow indirect selection for rust resistance independent of environmental effects (Rai et al., 2011). For the development of rust resistant varieties there is need for phenotypic screening as well as molecular screening of existing lines/ germplasms/cultivars. Several researches that have been carried from past in these aspects are mentioned below:

Pal et al., (1980) screened a total of 292 accessions of pea (Pisum spp.) under field conditions for resistance to powdery mildew (Erysiphe polygoni) and rust (Uromyces fabae). Only three accessions--PJ207508, PJ222117, and EC109188-were resistant to rust. PJ207508 was resistant to both powdery mildew and rust disease. Likewise, Kumar et al., (1994) tested thirty tall genotypes of field pea against rust severity. Variety Pant P-8 had lowest pea rust cover under disease progress curve (AUDPC) value, growth rate (c) and apparent infection rate (r). However, in general KFP 106, DMR 11, HUP 8603, type 163 and KPMR 22 showed high level of slow resistance, being conditioned by a number of genes with small effects is more desirable. Similarly, total of 648 accessions of Vicia faba was screened for resistance to faba bean rust (Uromyces viciae-fabae) by Sillero et al., 2000. They identified two distinct types of resistance, both resulting in reduced disease severity (DS) and area under the disease progress curve (AUDPC), but differing in the expression of hypersensitivity i.e. one as incomplete non hypersensitive resistance and the other as incomplete resistance with late hypersensitivity. These two types of resistance were characterized by three macroscopic components of resistance: increased latent period (LP), decreased colony size (CS) and a relatively reduced infection frequency (IF), both on seedlings and on adult plants. Xue and Warkentin (2002) studied 93 field pea varieties to three isolates of $U$. viciae-fabae with symptoms (LAS) under control condition. Significant difference $(\mathrm{P}<0.5)$ was observed from pea varieties and rust isolates, and variety $\mathrm{x}$ isolate interaction. Similarly, three hundred and forty five accessions of pea of diverse origin, height, leaf types and disease reaction were screened for rust disease severity and area under disease progress curve (AUDPC) by Chand et $a l$. , 2006. Of the 345 accessions, forty-four genotypes were evaluated for disease intensity, which was converted into AUDPC, number of pustules/leaf and pustule size. They found fast rusting genotypes exhibiting lower AUDPC, accompanied with increased seed yield and seed weight when grown under the protected condition, as compared to those raised under the unprotected condition whereas the genotypes Pant P 11, FC 1, HUDP 16, JPBB 3 and HUP 14 appeared as slow rusting genotypes. Kushwaha et al., 
(2007) conducted field and polyhouse studies to determine the appropriate time for the assessment of slow rusting in pea to Uromyces fabae (Pers de Bary). The critical time occurred when disease severity on the susceptible (check) genotype HUVP 1 had crossed $90 \%$ but was $<20 \%$ on the resistant (check) genotype FC 1.The disease assessment at critical time revealed precise differentiation between resistance and susceptible reactions in the $\mathrm{F}_{2}$ generation of the cross HUVP 1/ FC 1. Reduction in 100seed weight of inoculated F3 progeny rows showed high correlation with rust severity at the critical time and AUDPC based on two assessments in the field. Significant reduction in 100-seed weight was observed only for susceptible lines whereas; reductions in moderately resistant and resistant lines were not significant. Mishra et al., (2009) evaluated 107 genotypes of field pea against rust (Uromyces viciae-fabae), out of which genotypes P 9-77, P 2432; P2572 and P 2930 were found resistant, whereas 27 exhibited moderate reaction. Likewise, total of 2759 pea accessions was screened for resistance against Uromyces pisi (Pers.) Wint by Barilli et al., (2009). All accessions displayed a compatible interaction (high infection type) both in adult plants under field conditions and in seedlings under growth chamber conditions, but with varying levels of disease reduction. The identified resistance was based on reduction of disease severity with no associated host cell necrosis, which fits the definition of Partial Resistance. No complete resistance or incomplete resistance based on hypersensitivity was observed. In present era, molecular markers associated with pea rust resistance would be useful in marker assisted selection (MAS). Utility of molecular markers associated with the pea rust resistance were evaluated in 30 diverse pea genotypes using four SSR markers (AA446 and AA505 flanking the major QTL Qruf; AD146 and AA416 flanking the minor QTL, Qruf1) by
Singh et al., (2015). QTL, Qruf flanking markers were able to identify all the resistant genotypes when used together, except Pant $\mathrm{P}$ 31. While, SSR markers AD146 and AA416 flanking the minor QTL, Qruf1 were able to identify all the pea resistant genotypes used for validation, except for HUDP-11 by AD146 and Pant P 31 by AA416. Similarly, SSR markers AA446 and AA505 were able to identify all the susceptible pea genotypes, except IPFD 99-13, HFP 9415 and S- 143. SSR markers AD146 and AA416 were together able to identify all the pea susceptible genotypes used for validation, except KPMR 526, KPMR632 and IPFD 9913. On the basis of marker allele analysis, they concluded that SSR markers (AA446, AA505, AD146 and AA416) can be used in MAS of pea rust resistance. Rai et al., (2011) suggested that the Ruf gene proposed by Vijayalakshmi et al., (2005) be now redesigned as Qruf to signify the quantitative nature of its action and detected another minor quantitative trait loci (QTL) (named Qruf1). Both QTLs were located on LGVII. Qruf was flanked by SSR markers, AA505 and AA446 (10.8 cM), explaining 22.2$42.4 \%$ and $23.5-58.8 \%$ of the total phenotypic variation for IF and AUDPC, respectively. Qruf was consistently identified across four environments. Therefore, the SSR markers flanking Qruf would be useful for marker-assisted selection for $U$. viciae-fabae resistance. The minor QTL was environmentspecific, and it was detected only in the polyhouse (logarithm (base 10) of odds values 4.2 and 4.8). It was flanked by SSR markers, AD146 and AA416 (7.3 cM), and explained $11.2-12.4 \%$ of the total phenotypic variation. Similarly, Upadhyay et al., (2017) screened 46 numbers of total germplasms, out of which two germplasms Pant P 244 and Pant P 42 showed moderate resistant, 13 germplasms were moderately susceptible, 29 germplasms were found susceptible and two germplasms HFP-4 and HUVP 1 were found highly 
susceptible. Moderately resistant germplasm showed low AUDPC value (160.83-188.33) with slow infection rate (0.054-0.062). Pustule appeared on these genotypes were small $(1.5-1.7 \mathrm{~mm})$ as compare to other susceptible genotypes whereas moderately susceptible genotypes scored AUDPC value from 175.83-437.50 with infection rate of 0.051-0.095. Size of the pustules showed high variation of $1.3-4.4 \mathrm{~mm}$. Genotypes with susceptible reaction showed AUDPC value of 292.50-797.50. Infection rate was ranged from $0.055-0.113$ with pustule size of 2.9$4.8 \mathrm{~mm}$. Those genotypes which fall under highly susceptible reaction (HFP-4 and HUVP-1) scored highest AUDPC value of 1078.33-1223.33 with 0.064-0.075 infection rate. They showed largest pustule size of 4.24.6mm. Upadhyay and co-workers (2017) also did molecular screening of 32 number of phenotypically selected genotypes using four SSR markers - AA446 and AA505 flanking the major QTL Qruf; AD146 and AA416 flanking the minor QTL, Qrufl associated with pea rust resistance. They have also concluded that SSR markers (AA446, AA505, AD146 and AA416) if used together, can be effective in marker assisted selection (MAS) of pea rust resistance.

Molecular markers linked to resistance genes could helps in assisting the selection of rust resistant segregants and thus improve efficiency of breeding. So far, works on molecular mapping of resistance against $U$. pisi are inadequate and more strong markers are required.

Breeding works for rust resistance is slow due to still inadequate genomic resources and because of the limited knowledge of the biology of various rust pathogens, their existence of races and their distribution. Therefore, to provide significant input in this area, it is important to improve the existing knowledge of biology of the causal agents as well as of the plant, resistance breeding will be efficiently accelerated.

\section{Induction of host defence through biotic and abiotic elicitors}

Plants can be induced for a more rapid or extra intense mobilization of defence responses leading to improved resistance to biotic or abiotic stresses (Beckers and Conrath, 2007). Many factors such as prior pathogen attack (biotic) and various chemical and environmental stimuli (abiotic) may act on plants to induce systemic acquired resistance (SAR) to subsequent pathogen attack (Kauss et al., 1992; Kessmann et al., 1994; Dann and Deverall, 1995; Barilli et al., 2010). SAR has been reported to be effective against a broad spectrum of pathogens including viruses, fungi, bacteria, nematodes and parasitic weeds (Beckers and Conrath, 2007). Induction of systemic resistance is associated with gene induction, the activation of a wide range of resistance mechanisms and the production of a wide range of defence compounds. It is race non-specific and is often effective against a broad spectrum of pathogenic agents (Kuc, 1995; Walters and Fountaine, 2009). Thus, study on induction of host defence through biotic and abiotic elicitors can be considered as one of the effective sustainable approaches in disease management.

Walters and Murray (1992) observed that inoculation of the lowest two leaves of broad bean (Viciae fabae) with urediospores of the rust fungus ( $U$. viciae fabae), caused the upper leaves to become resistant to challenge inoculation with the same pathogen one, three, six and nine days later. The resistance was observed as diminished infected areas on the leaves and fewer uredia per standard area for up to 29 days from challenge inoculation. The resistance was very high when the difference between treatment and challenge 
inoculation was one day but had disappeared when 12 days separated the two. In further experiments, Walters and Murray (1992) reported that treatment of the first two leaves with either $10 \mathrm{mM}$ tri-potassium phosphate or $5 \mathrm{mM}$ ethylene diamine tetraacetic acid (EDTA) also induced development of resistance in upper leaves to challenge inoculation and the induced resistance was observed for 21 days after challenge inoculation. Rust infection was reduced by 15.0 and 34.0 per cent, if the upper leaves were inoculated $24 \mathrm{hrs}$ after potassium phosphate or EDTA treatment respectively while, there was 77.0 per cent reduction in infection if the interval between treatment and inoculation was increased to 12 days. Dann and Dever all (1995) reported that inoculation of unifoliate leaves of nine days old green bean (Phaseolus vulgaris) with spore suspension of Colletotrichum lindemuthianum $\left(10^{4}\right.$ conidia/ml $)$, causing local lesions, or spraying with 2-6-dichloroisonicotinic acid $(20 \mu \mathrm{g} / \mathrm{ml})$ induces development of resistance in the upper leaves against challenge inoculation of $U$. appendiculatus afterwards. Rauscher et al., (1999) reported that treatment of broad bean leaves with salicylic acid or 2, 6 , dichloroisonicotinic acid induces resistance against the rust fungus Uromyces viciae-fabae resulting in reduced rust pustules density. Inhibition of the rust infection hyphae in acquired resistance broad bean plants was found mainly due to antifungal activity of PR1 protein synthesized in plants in response to salicylic acid or dichloroisonicotinic acid application. Dann and Deverall (2000) observed that, when inoculation of first expanded leaves of pea seedlings with an avirulent strain of Pseudomonas syringae pv. pisi or treatment with sprays of benzothiadiazole (20 or $100 \mathrm{mg} \mathrm{a.i/ml}$ ), decreased susceptibility of subsequent leaves 7 or 14 days later to challenge inoculation with Uromyces viciae-fabae causing pea rust was found. Effective treatment enhanced the activity of enzymes $\beta-1,3$ glucanase and chitinases in untreated upper leaves. Similarly, Katoch et al., (2005) observed that when pea (Pisum sativum L.) plants treated with different concentrations of salicylic acid and 4-aminobutyric acid increased activities of phenol metabolizing enzymes implicated in the defense of plants. The enzymes peroxidase, polyphenol oxidase, phenylalanine ammonia-lyase and superoxide dismutase responded to treatment with variation in their activities. Phenolic content also varied following treatment with the inducers. Similarly, Systemic acquired resistance (SAR) induction on plant-pathogen interaction was developed using both biotic (U. pisi and $U$. appendiculatus) and abiotic (salicylic acid (SA), benzo-(1,2,3)thiadiazole-7-carbothionic acid (BTH) and DL- $\beta$-aminobutyric acid (BABA)) inducers (Barilli et al., 2010b). Results obtained showed a significant reduction of infection levels locally and systemically with BTH and BABA foliar treatments, whereas neither biotic inducers nor SA had any significant effect hampering the rust development. Barilli et al., (2010a) found that Benzothiadiazole (BTH) and DL- $\beta$ - aminobutyric acid (BABA) induced systemic resistance in susceptible and resistant pea genotypes against Uromyces pisi. Resistance was characterized by reduced infection frequency mainly due to decreases in appressorium formation, stomatal penetration, growth of infection hyphae and haustorium formation. Changes in $\beta-1,3-$ glucanase, chitinase, phenylalanine ammonialyase and peroxidise activities and in total phenolics content, demonstrate that $U$. pisi resistance is induced by $\mathrm{BTH}$ and BABA treatments at early and late stages of the fungal infection process, but that the chemicals operate via different mechanisms.

Exogenous applications of salicylic acid (SA) and benzothiadiazole (BTH) solutions have been used in faba bean to induce systemic 
acquired resistance (SAR) to rust (Uromyces viciae-fabae), ascochyta blight (Ascochyta fabae) and broomrape (Orobanche crenata). Both SA and BTH solutions were effective inducing SAR to $U$. viciae-fabae and A. fabae on susceptible accessions under controlled conditions, although SA was less effective than BTH for A. fabae. BTH treatments reduced the infection of all pathogens studied under field conditions in susceptible accessions, and rust infection was also reduced by SA applications. Moderately resistant accessions became immune to ascochyta blight with BTH treatment, and showed a lower degree of infection to rust after SA or BTH treatments. No effect was observed in the highly resistant accessions (Sillero et al., 2012). Barilli et al., (2012) studied systemic acquired resistance (SAR) to Uromyces pisi in pea by using a proteomic approach. Two-dimensional electrophoresis (2-DE) was used in order to compare the leaf proteome of two pea genotypes displaying different phenotypes (susceptible and partial resistance to the fungus), and in response to parasite infection under the effect of two inducers of SAR, BTH and BABA. Multivariate statistical analysis identified 126 differential protein spots under the experimental conditions (genotypes/treatments). All of these 126 protein spots were subjected to MALDITOF/TOF mass spectrometry to deduce their possible functions. A total of 50 proteins were identified using a combination of peptide mass finger printing (PMF) and MSMS fragmentation. Most of the identified proteins corresponded to enzymes belonging to photosynthesis, metabolism, biosynthesis, binding and defence response, whose behavior pattern was different in relation to susceptibility/ resistance of the genotypes studied and to the $\mathrm{BTH} / \mathrm{BABA}$ induction to pathogen response. Results obtained in their work suggested that plants could reduce their photosynthesis and other energy metabolism and enhance the production of defence-related proteins to cope the stress. On the other side, they postulated that resistance induced by the chemicals operates via different mechanisms: BABA inducer could act via phenolic biosynthesis pathway, whereas resistance provided by BTH inducer seems to be mediated by defence and stress-related proteins. Recently, Upadhyay et al., (2016) studied total of fifteen elicitors tested alone/or in combination for induction of defense related enzymes in pea against $U$. viciaefabae (Pers.) J. Schrot. They observed significant induction of total phenols, peroxidase, polyphenol oxidase and phenylalanine ammonia lyase in all the treatment as compare to control. Salicylic acid, Pseudomonas fluorescens, salicylic acid + Pseudomonas fluorescens were found most effective in induction of total phenols and peroxidase at $72 \mathrm{hrs}$ after spray of elicitors. Polyphenol oxidase induction was found significantly high in oxalic acid, Pseudomonas fluorescens + Trichoderma harzianum and chitosan + Pseudomonas fluorescens at $72 \mathrm{hrs}$ after spray of elicitors. Among all the treatments, maximum induction of Phenylalanine ammonia lyase activity was found in oxalic acid, Trichoderma harzianum + Pseudomonas fluorescens and isonicotinic acid + Trichoderma harzianum after $48 \mathrm{hrs}$ of spray of elicitors. Effect of different elicitors on percent disease index (PDI) 20 days after inoculation with uredospores of $U$. Viciaefabae showed least PDI in salicylic acid, Trichoderma harzianum + Pseudomonas fluorescens and chitosan + Pseudomonas fluorescens treated plants.

\section{Chemical control}

Breeding for rust resistance is considered the most adequate control strategy, but only moderate levels of resistance are available in commercial cultivars. This reinforces the need 
to integrate several control strategies including chemical control. Therefore, search for the best fungicides in management of pea rust under field condition should be carried out in order to find out its effectiveness in integrated disease management (IDM) strategy. Many experiments were previously conducted to find out the efficacy of fungicides which are mentioned here under:

Several inorganic sulphur preparations are reported to give effective control of $U$. fabae (El-Healy, 1939; Zaumeyer, 1946; Jacks, 1954; Accantino, 1964). Similarly, organic sulphur fungicides like ferbam, ziram, thiram and zineb have been reported to give good control of $U$. fabae (Jacks, 1954; Jacks and Webb, 1956; Accantino, 1964). Hiremath and Pavgi (1971) obtained complete inhibition of aeciospores germination of $U$. fabae with aureofungin to $20 \mu \mathrm{g} / \mathrm{ml}$ and recommended early application of higher aureofungin concentrations to control rust disease. Sugha et al., in 1994 reported sensitivities of aeciospores and urediospores to benzimidazole and triazole fungicides. They concluded that benomyl, carbendazim, thiobendazole and thiophanate methyl have very good potential for suppressing the early establishment of pea due to aeciospores, whereas benomyl, flutriafol and mycobutanil should be effective in suppressing the late infection due to urediospores. Likewise, Ayub et al., (1996) evaluated six fungicides namely, propineb $(0.2 \%)$, tridemorph $(0.1 \%)$, tebuconazole $(0.1 \%)$, oxycarboxin $(0.2 \%)$, carbendazim $(0.2 \%)$ and propiconazole $(0.05 \%)$ for their ability to control Uromyces viciae fabae, the cause of lentil rust. According to them, Tilt gave the best control, reducing rust intensity and increased pod yield. Folicur and calixin were also effective against the disease. Similarly, Huge and Nahar (1997) tested four fungicides, propiconazole, triademorph (calixin 75 EC) tebuconazole (folicur $25 \mathrm{EC}$ ) and sulfur (thiouit) under field conditions for their ability to control rust (Uromyces viciae-fabae) in peas (Pisum sativum). Four sprays with tebuconazole $(0.05 \%)$ was found highly effective in controlling the disease and was the most economical in term of crop yield $(605.87 \mathrm{~kg} / \mathrm{ha})$ and net profit, with a benefit cost ratio 5.69. Gupta and Shyam (1998) also tested the efficacy of triademefon, hexaconazole, difenaconazole, flusilazole, fenarimol, penconazole, mancozeb and chloro-thalonil for the rust control. They found hexaconazole $(0.10 \%)$ and difenaconazole $(0.01 \%)$ were best against rust and increase yield. Similarly, Singh and Tripathi (2004) tested ten different fungicides against rust of pea in a field experiment and they found that two to three sprays of Baycor $0.1 \%$ at 15 days interval was most effective in reducing the disease severity and resulted in appreciable increase in grain yield. Likewise, Sugha et al., (2008) evaluate the efficacy of 22 fungicides against pea rust during crop (rabi) at farmer's field. They observed that three fortnightly foliar sprays, starting with the appearance of disease, individually of bayleton, score, tebuconazole (folicur and tebuconazole) and hexaconazole (contaf and sitara) among systemic and at 10 days intervals of antracol and microsul share among non-systemic fungicides proved effective for combating the disease and in ameliorating the crop yield significantly. Khan et al., (2009) conducted research to find out the response of five different pea cultivars and efficacy of three different fungicides against Uromyces pisi (Pers) de Barry under field conditions for the control of pea rust. He found that all fungicides caused reduction in disease severity. The lowest disease attack was recorded in plants treated with Mancozeb followed by those with Bayleton showing a subsequent increase in yield. The effectiveness of eleven foliar-applied fungicides on faba bean rust (Uromyces viciae-fabae (Pers.) J. Schröt.) and on the 
seed yield of faba bean (Vicia faba L.) were studied in growth chambers and in the field by (Emeran et al., 2011). Fungicides were tested at recommended and reduced rates. All the fungicides tested provided very effective preventive control in their growth chamber studies. Triazoles (difenoconazol, epoxiconazol, tebuconazol) and their mixtures with benzimidazoles (carbendazim-flutriafol and carbendazim-flusilazole) provided the most effective curative effect, even at $25 \%$ of recommended concentrations which were followed by dithiocarbamates, copper dithiocarbamate mixture, carboxamide and chlorothalonil. Triazoles, benzimidazoletriazole mixtures and carboxamide maintained their effect until 15 days after fungicide application.Under field conditions, rust infection caused $22-26 \%$ yield reduction.

All fungicides except mancozeb caused a significant decrease in disease severity under field conditions, but only treatments with triazoles and benzimidazole-triazole mixtures provided significant yield increases (22.7$15.6 \%$ ) when applied twice. Three applications of oxycarbosin or coppermancozeb were needed to provide a significant yield increase. Dithiocarbamates (thiram, maneb or mancozeb) or chlorothalonil reduced rust severity but did not provide a significant yield increase (Emeran et al., 2011).

Similarly, Singh (2012) conducted experiment to control the pea rust disease with foliar sprays of new strobilurin fungicides viz. Amistar and triazoles viz. Score (difenoconazole) and Tilt (propiconazole) in different combinations. He found a very significant disease control of $81.8 \%$ was obtained when two sprays of Score @0.1\% were given at 20 days interval followed by Score@0.05\% (66.5\%). The minimum disease severity of $15.05 \%$ was observed with Score@0.1\% over control plots. Basandrai et al., (2013) evaluated some commercially available fungicides for pea rust management. They found that three foliar sprays of tebuconazole $250 \mathrm{EFW}$ resulted in the least mean rust disease severity $(6.2 \%)$ followed by propiconazole 25 EC $(23.7 \%)$ and hexaconazole 5 EC (26.1\%) compared with $52.2 \%$ in no spray check. Similarly, Upadhyay et al., (2018) tested the efficacy of total of sixteen chemicals fungicides alone and/or in combination against rust disease of pea.

Their study revealed that all the sixteen fungicides were found effective for the management of disease as compare to control (water spray). However tebuconazole, carbendazim + tebuconazole, Mancozeb + tebuconazole, carbendazim + flusilazole, penflufen + trifloxystrobin were found equally and very effective among all. These fungicides showed considerable reduction in rust severity (12.50-16.67\%) and area under disease progress curve (AUDPC) value (195.83-291.67) with high total yield (86.72$76.30 \mathrm{~kg} / \mathrm{ha}$ ) and test weight (160.94-180.93 g) as compare to control which showed highest rust severity (54.17\%) and AUDPC value (1058.33) with lowest total yield $(405.30 \mathrm{~kg} / \mathrm{ha})$ and test weight (144.0g). Correlation of AUDPC values with test weight and total yield were found significantly negatively correlated whereas no correlation was found with apparent rate of infection.

Out of various disease management approaches, each one of them has its own importance in managing the rust disease of pea. But, if each approach can be integrated with each other in best manner, they can perform more effectively. However, the compatibility of these combinations needs to be carried out in field condition before being adopted. 


\section{References}

Accatino, P.. Chemical control on lentil rust. Agric. Tech. 1964 23-24: 7- 14 (Rev. Appl. Mycol., 1967: 205).

Alexopolus CJ, Mims CJ and Blackwell M. Introductory Mycology. John Wiley and Sons. Inc. 1996; pp 869.

Arthur JC and Cummins GB. Manual of rusts in United States and Canada. Hafner Publishing Co. 1962; 438pp.

Ayub A, Rahman MZ, Ali S and Khatun A. Fungicidal spray to control leaf rust of lentil. Bangladesh J. Plant Pathol. 1996; 12: 61-62.

Bal RS and Kumar A. Influence of weather parameters on pea rust development and its effect on yield. Pl. Dis. Res. 2012; 27: 162-164.

Barilli E, Rubiales D and Castillejo MA. Comparative proteomic analysis of $\mathrm{BTH}$ and BABA-induced resistance in pea (Pisum sativum) toward infection with pea rust (Uromyces pisi). J. Proteomics, 2012; 75: 5189-5205.

Barilli E, Prats E and Rubiales D. Benzothiadiazole and BABA improve resistance to Uromyces pisi (Pers.) Wint. in Pisum sativum L. with an enhancement of enzymatic activities and total phenolic content. Eur J Plant Pathol. 2010a; 128: 483-493.

Barilli E, Rubiales D and Castillego MA. Comparative proteomic analysis of $\mathrm{BTH}$ and BABA-induced resistance in pea (Pisum sativum) toward infection with pea rust (Uromyces pisi). J. Proteomics. 2010; 75: 5189-5205.

Barilli E, Sillero JC and Rubiales D. Induction of systemic acquired resistance in pea against rust (Uromyces pisi) by exogenous application of biotic and abiotic inducers. J. Phytopathol. 2010b; 158: 30-34.

Barilli E, Sillero JC, Aparicio MF and
Rubiales D. Identification of resistance to Uromyces pisi (Pers.) Wint. in Pisum spp. Germplasm. Field Crop Res. 2009; 114: 198-203.

Baruah HK. Text book of Plant Pathology. Oxford and IBH, 1980; New Delhi.

Basandrai A K, Basandrai D, Mittal P and Sharma BK. Fungicidal management of rust, powdery mildew and Ascochyta blight in seed crop of pea. Pl. Dis. Res. 2013; 28: 22-28.

Bayaa B and Erskine W. Diseases of lentils. In: Allen DJ and Lenné JM (eds.) The Pathology of Food and Pasture Legumes, CAB International and ICRISAT, Wallingford, UK. 1998; pp. 423-471.

Beckers GJM and Conrath U. Priming for stress resistance: from the lab to the field. Curr. Opin. Plant Biol. 2007; 10: 425-431.

Bhardwaj ML and Sharma JM. Performance of early pea genotypes under different sowing times in the hills of Himachal Pradesh. J. Hill. Res. 1996; 9: 62-64.

Bilgrami KS, Jamaluddin S and Rizvi MA. The fungi of India part I (list and references). Today and Tomorrow's Printers and Publishers, 1979; New Delhi.

Brown JK and Hovmoller MS. Aerial dispersal of pathogens on the global and continental scales and its impact on plant disease. Science. 2002; 297:537-541.

Butler EJ. Fungi and diseases in plants. Thatcher, Spink Co. Calcutta, 1918; 547 pp.

Chand R, Srivastava CP and Kushwaha C. Screening technique for pea (Pisum sativum L.) genotypes against rust disease (Uromyces fabae Pers. de Bary). Indian J. Agric. Sci. 2004; 74: 166-167.

Chand R, Srivastava CP, Singh BD and Sarode SB. Identification and 
characterization of slow rusting components in pea (Pisum sativum L.). Genet. Resour. Crop. Ev. 2006; 53: 219-224.

Chand R, Srivastava CP, Singh RM and Singh RB. Pea specific strains in Uromyces fabae. Indian J. Pul. Res. 1997; 10: 127-128.

Chauhan, RS. Epidemiology and control of pea rust caused by Uromyces viciaefabae (Pers.) de Bary. M. Sc. Thesis, Deptt. Of Plant Pathology, HPKV, Plampur, India. 1988; 109pp.

Chauhan RS and Singh BM. Effect of different durations of leaf wetness on pea rust development. Plant Dis. Res. 1995; 9: 200-201.

Chauhan RS, Sugha SK and Singh BM. A note on the prevalence and distribution of pea rust in Himachal Pradesh. Him. J. Agric. Res. 1991; 17: 105-107.

Conner RL and Bernier CC. Host range of Uromyces viciae-fabae. Phytopathoogy. 1982; 72: 687-689.

Dann EK and Deverall BJ. Effectiveness of systemic resistance in bean against foliar and soilborne pathogens as induced by biological and chemicals means. Plant Pathol. 1995; 44: 458466.

Dann EK and Deverall BJ. Activation of systemic disease resistance in pea by an avirulent bacterium or a benzothiadiazole, but not by fungal leaf spot pathogens. Plant Pathol. 2000; 49: 324-332.

De Bary A. Morphologie and Physiologie-der plize Flechten und Myxomyceten; 1862.

Deutelmoser E. Plant protection using natural defence system of plants. Adv. Plant Patho. 1926; 11: 211-228.

Duke JA. and Ayensu ES. Medicinal Plants of China. Reference Publications. Inc.: ISBN 0-917256-20-4. Reference Publications, Algonac, 1985; MI
(USA).

El-Helaly, AF. Bordeaux mixture for the preventation of rust and chocolate spot of beans. Phytopathology, 1950; 40: 699-701.

Emeran AA, Sillero JC, Fernández-Aparicio M. and Rubiales D. Chemical control of faba bean rust (Uromyces viciaefabae). Crop Prot. 2011; 30: 907-912.

Emeran AA, Sillero JC, Niks RE and Rubiales D. Infection structures of host-specilized isolates of Uromyces viciae-fabae and of other species of Uromyces infecting leguminous crops. Plant Dis. 2005; 89: 17-22.

Gaumann EA. Comparative morphology of fungi. Translated by Caroll Willian Dodge, Biotech Books, Delhi. 1998; pp: 563.

Gupta RP. Evaluation of pea germplasm for their reaction to powdery mildew and rust. Indian J. Pul. Res. 1990; 3: 186188.

Gupta SK and Shyam KR. Control of powdery mildew and rust of pea by fungicide. Indian Phytopathol. 1998; 51: 184-186.

Hahn M, Neef U, Struck C, Gottfert M and Mendgen K. A putative amino-acid transporter is specifically expressed in haustoria of the rust fungus Uromyces fabae. Mol. Pl. Microb. Interact. 1997; 10: 438-45.

Hazarika DK, Dubry LN and Das KK. Effect of leaf spots and rust of groundnut. J. Mycol. and Pl. Pathol. 2000; 30: 2730.

Hiremath RV and Pavgi MS. In-vitro assay of aureofungin against some rust fungi, Hind. Anti. Bull. 1971; 13: 83-86.

Huang BF and Staples RC. Synthesis of proteins during differentiation of the bean rust fungus. Exp. Mycol. 1982; 6: 7-14.

Huge HI and Nahar MS. Efficacy and economics of different fungicides in 
controlling rust and powdery mildew of garden pea, Bangladesh. J. Sci. Indust. Res. 1997; 32: 533-536.

Indian Institute of Pulses Research (IIPR), EPulses data book. 2014.

Jacks H. Screening test with fungicides for control of broad bean rust. N.Z.J. Sci. Tech. Sect. A. 1954; 36: 274-279 (Rev. Appl. Mycol., 1955: 623).

Jacks $\mathrm{H}$ and Webb AJ. field tests for control of broad bean rust. N.Z.J. Sci. Tech. Sect. A. 1956; 38: 157-159 (Rev. Appl. Mycol., 1957: 160).

Joshi A and Tripathi HS Studies on epidemiology of lentil rust (Uromyces viciae fabae). Indian Phytopath. 2012; 65 (1): 67-70.

Rai OP and Gupta RP. Effect of sowing date and population density on yield and rust in dwarf pea. Indian J. pulses res. 2003; 16(1): 34-35.

Kapooria RG and Sinha S. Studies on the host range of Uromyces fabae (Pers.) de Bary. Indian Phytopathol. 1966; 95: 229-230.

Katoch R, Mann APS and Sohal BS. Enhanced Enzyme Activities and Induction of Acquired Resistance in Pea with Elicitors. J. Veg. Sci. 2005; 11: 67-83.

Kauss H, Theisinger-Hinkel E, Mindermann $\mathrm{R}$ and Conrath U. Dichloroisonicotinic and salicylic acid, inducers of systemic acquired resistance, enhance fungal elicitor responses in parsley cells. Plant J. 1992; 2: 655-660.

Kessmann H, Staub T, Hofmann C, Maetzke $\mathrm{T}$, Herzog J, Ward E, Uknes $\mathrm{S}$ and Ryals J. Induction of systemic acquired disease resistance in plants by chemicals. Annu. Rev. Phytopathol. 1994; 32: 439-459.

Khan IA, Khan H, Ali A, Raziq F, Hussain S, Ahmad $\mathrm{M}$ and Attauddin. Evaluation of various fungicides and cultivars for the control of pea rust under natural conditions. Sarhad J. Agric. 2009; 25(2):261-268.

Khare $\mathrm{MN}$ and Agrawal SC. Lentil rust severity survey in Madhya Pradesh. Proceedings of All India Pulse Workshop, Baroda. 1978; 3p.

Kirk PM, Cannon PF, David JC and Stalpers JA. Dictionary of the Fungi, $9^{\text {th }}$ edn.Wallingford, UK: $\quad$ CAB International. 2001; ISBN085199377X.

Kirk PM, Cannon PF, Minter DW and Stalpers JA. Dictionary of the Fungi, $10^{\text {th }}$ edn. Wallingford, UK: CAB International. 2008.

Kuc J. Phytoalexins, stress metabolism, and disease resistance in plants. Annu. Rev. Phytopathol. 1995; 33: 275-297.

Kumar TBA, Rangaswmy KT and Ravi K. Assessment of tall field pea genotypes for slow rusting resistance. 1994; Legume Res., 17: 79-82.

Kushwaha C, Srivastava CP, Chand R and Singh BD. Identification and evaluation of a critical time for assessment of slow rusting in pea against Uromyces fabae. Field Crop. Res. 2007; 103: 1-4

Lal HC, Upadhyay JP; Jha AK and Kumar A. Survey and surveillance of lentil rust and its cross infectivity on different host. J. Res. 2007; 19: 111-113.

Mayer E. Mycological notes- XII. Bull. Soc. Neuchatel, Sci. Nat. 1947; IXX: 33-60 (Rev. Appl. Mycol., 1948:158).

Mendegen K. The Uredinales. The Mycota Vol. V Plant Relationships Part B (Esser K \& Lemke PA, eds), pp. 7994. Springer-Verlag, Berlin. 1997; 57: 267-276.

Mishra RK, Pandey KK and Pandey, PK. Screening of pea (Pisum sativum) genotypes against rust caused by Uromyces fabae. Indian J. Agr. Sci. 2009; 79: 402-403.

Mittal RK. Effect of sowing dates and disease 
development in lentil as sole and mixed crop with wheat. J. Mycol. Pl. Pathol. 1997; 27: 203-209

Mitter $\mathrm{JH}$ and Tondon RN. Fungi flora of Allahabad, India. J. of Indian Botanical Society, 1930; 9: 190-196.

Narsinghani VG, Singh SP and Pal BS. Note on rust resistance pea varieties. Indian J. Agric. Sci. 1980; 50: 453.

National Council of Applied Economic Research (NCAER). 2014; India's Pulses scenario.

Negussie T, Pretorius ZA and Bender CM. Effect of some environmental factors on in vitro germination of urediniospores and infection of lentils by rust. J. Phytopathol. 2005; 153: 43 47.

Pal AB, Brahmappa R, Rawal D and Ullasa BA. Field resistance of pea germplasm to powdery mildew (Erysiphe polygoni) and rust (Uromyces fabae). Plant Dis. 1980; 64: 1085-1086.

Palter $\mathbf{J}$ and Stetbiner M. The principal pests and diseases affecting legume crops in spring. Adv. Leadl. Agric. Consult. 1957; 20: 15 (Rev. Appl. Mycol., 1957: 530).

Pavgi MS and Upadhyay HP. Parasitic fungi from North India VI. Mycopathologia et mycologia applicata. 1966; 30: 527 260.

Persoon DCH. Synopsis methodica fungorum. 1801; 1: 224.

Prasada R and Singh SP. Sexual behavior of Uromyces fabae. Indian J. Mycol. Pl. Pathol. 1975; 5: 139-144.

Prasada R and Verma UN. Studies on lentil rust, Uromyces fabae. Indian Phytopathol. 1948; 1: 142-146.

Rai R, Singh AK, Singh BD, Joshi AK, Chand $\mathrm{R}$ and Srivastava $\mathrm{CP}$. Molecular mapping for resistance to pea rust caused by Uromyces fabae (Pers.) de-Bary. Theor. Appl. Genet. 2011; 123: 803-813.
Rana KS and Sharma SK. Effect of rabi legumes on nitrogen economy and productivity of direct seeded upland rice. Crop Res. 1993; 6: 165-167.

Rausher M, Adam AL, Wirtz S, Guggenheim $\mathrm{R}$, Mendegen $\mathrm{K}$ and Deising $\mathrm{H}$. PR-1 protein inhibits the differentiation of rust infection hyphae in leaves of acquired resistant broad bean. Plant J. 1999; 19: 625-633.

Roy TC. Fungi of Bengal: Directorate of Agriculture. 1949; Govt. of West Bengal.

Sadravi M, Ono Y, Pei M and Rahnama K. Fourteen rusts from Northern Iran. J. Plant Pathol. 2007; 89: 191-202.

Sangar RB and Singh VK. Effect of sowing dates and pea varieties on the severity of rust, powdery mildew and yield. Indian J. Pul. Res. 1994; 7: 88-89.

Sharma AK. Epidemiology and management of rust disease of French bean. Veg. Sci. 1998; 25: 85-88.

Sillero JC, Moreno MT and Rubiales D. Characterization of new sources of resistance to Uromyces viciae-fabae in a germplasm collection of Vicia faba. Plant Pathol. 2000 49: 389-395.

Sillero JC, Rojas-Molina MM, Avila CM and Rubiales D. Induction of systemic acquired resistance against rust, ascochyta blight and broomrape in faba bean by exogenous application of salicylic acid and benzothiadiazole. Crop Prot. 2012; 34: 65-69.

Singh AK, Rai R, Singh BD, Chand R, Srivastava CP. Validation of SSR markers associated with rust (Uromyces fabae) resistance in pea (Pisum sativum L.). Physiol. Mol. Biol. Plant. 2015; 21: 243-247.

Singh BR. Efficacy of some triazole and strobilurin fungicides against pea rust. Pl.Dis.Res. 2012; 27: 162-164.

Singh C. Modern techniques of raising field crops. Published by mohan primlane 
oxford and IBH. Publishing Co. 66. 1984; New Delhi pp. 521.

Singh D and Tripathi HS. Epidemiology and management of field pea rust. J. Mycol. Pl. Pathol. 2004; 34: 675-79.

Singh D, Kumar A and Singh AK. Influence of planting time, planting geometry, intercropping and row direction on rust (Uromyces viciae fabae) pers. de Bary of field pea (Pisum sativum 1.). Legume Res. 2014, 37: 542-546.

Singh D, Tripathi HS, Singh AK and Gupta AK. Effects of sowing dates and weather parameters on severity of field pea. J.Pl.Dis.Sci. 2012; 7: 147149.

Singh RM and Srivastava CP. Evaluation, classification and usefulness of pea germplasm lines for quantitative characters. Legume Res. 1985; 8: 6873.

Singh RR, Mohit Singh and Singh M. Chemical control of pea rust. Ann. Pl. Prot. Sci. 1996; 5(1): 118-119.

Singh RS. Plant Diseases. Oxford and IBH, New Delhi. 1973; 512p.

Singh,V.K; Sangar, R.B.S and Singh, R.N. Effect of varieties and sowing dates on disease incidence and productivity of field pea (Pisum sativum). Indian J.Agron. 1995; 4: 451-453.

Sokhi HS, Sokhi SS and Rawal RD. Vertical reaction of pea to powdery mildew (Erysiphe polygoni) and rust (Uromyces vicia fabae). Mysore J. Agril. Sci. 1974; 8: 529-532.

Sugha SK, Banyal DK and Rana SK. Management of pea (Pisum sativum) rust (Uromyces fabae) with fungicides. Indian J. Agric. Sci. 2008; 78: 269-271.

Sugha SK, Chauhan RS and Singh BM. Sensitivity of aeciospores and urediospores of pea rust pathogen to selected systemic fungicides. Trop. Agric. 1994; 71: 27-30.
Thatcher PS. Osmatic and permeability relations in the nutrition of fungus parasite. Amer. J. Bot. 1939; 26: 44958.

Tripathi HS and Rathi YPS. Studies on epidemiology and management of rust of field pea. Final Technical Report, CAS in Plant Pathology, G.B.P.U.A \& T., Pantnagar, Uttarakhand. 2003; pp 125.

Upadhyay V, Kushwaha KPS and Pandey P. Inspection of different localities in Uttarakhand and Uttar Pradesh for the prevalence of rust disease of pea (Pisum sativum.). Trends in biosciences, 2015; 8 (16): 4336-4340.

Upadhyay V, Kushwaha KPS, Pandey P. Evaluation of Pea Germplasms for Rust Disease Resistance. J. Pure Appl. Microbio. 2017; 11 (1): 307-314.

Upadhyay V, Kushwaha K.P.S., Pandey P. Influence of weather parameters on progress of rust disease severity in Pea (Pisum sativum L.). J. Appl. Nat. Sci., 2017; 9 (3): 1724-1728.

Upadhyay V, Kushwaha KPS, and Pandey P. Evaluation of potential fungicides for the management of pea rust under field condition. International journal of chemical studies, 2018; 6 (2): 30853090.

Upadhyay V, Pandey P, Singh A, and Kushwaha KPS. Management of U. Viciae-Fabae (Pers.) J. Schrot in Pisum sativum $\mathrm{L}$. through alteration in sowing time. International journal of chemical studies, 2018; 6 (2): 32263230 .

Upadhyay V, Kushwaha KPS and Pandey P. Molecular screening of Pea Germplasm for Rust Disease Resistance. J. Pure Appl. Microbio. 2017; 11 (1): 343-348.

Upadhyay V, Kushwaha KPS and Pandey P. Evaluation of abiotic and biotic elicitors for induction of defense 
related enzymes in pea against $U$. Viciae-Fabae (Pers.) J. Schrot. Vegetos, 2016; 29 (3): 67-73.

Uppal BN. Host range of U. viciae-fabae. Int. Bull. Prot. 1993; 7: M 103, and M746.

Vavilov NI. Studies on the origin of cultivated plants. Bull. Appl. Bot., Genet. and Plant Breed. 1926; 26: 1248.

Vijayalakshmi S, Yadav K, Kushwaha C, Sarode SB, Srivastava CP, Chand R and Singh BD. Identification of RAPD markers linked to the rust (Uromyces fabae) resistance gene in pea (Pisum sativum.). Euphytica, 2005; 144:265274.

Walters DR and Fountaine JM. Practical application of induced resistance to plant diseases: an appraisal of effectiveness under field conditions. J. Agric. Sci. 2009; 147: 523-535.

Walters DR and Murray DC. Induction of systemic resistance to rust in Vicia faba by phosphate and EDTA: effects of calcium. Plant Pathol. 1992; 41: 444-448.

Xue AG and Warkentin TD. Reaction of field pea varieties to three isolates of Uromyces fabae. Cana. J. Pl. Sci. 2002; 82: 253-255.

Zaumeyer WJ. Field control of bean rust with sulphur. Phytopath. 1946; 36: 689.

\section{How to cite this article:}

Vinod Upadhyay, Kuldip Medhi, Puja Pandey, Palash Thengal, Sunil Kumar Paul and Kushwaha, K.P.S. 2019. Rust Disease of Pea: A Review. Int.J.Curr.Microbiol.App.Sci. 8(04): 416-434. doi: https://doi.org/10.20546/ijcmas.2019.804.046 